UDC 614.78

DOI: $10.21668 /$ health.risk/2019.4.03.eng

\title{
HEALTH RISK ANALYSIS RELATED TO EXPOSURE TO AMBUENT AIR CONTAMINATION AS A COMPONENT IN THE STRATEGY AIMED AT REDUCING GLOBAL NON-INFECTIOUS EPIDEMICS
}

\author{
V.N. Rakitskii, S.L. Avaliani, S.M. Novikov, T.A. Shashina, N.S. Dodina, V.A. Kislitsin \\ F.F. Erisman Federal Scientific Centre of Hygiene, 2 Semashko Str., Mytishchi, 141014, Russian Federation
}

\begin{abstract}
The article dwells on the analysis of the latest world data indicating that ambient air contamination is one of the most significant risk factors causing non-infectious diseases. Adverse effects produced on health are the most evident among sensitive population groups (women, children, and elderly people).

It was noted that risk management with well-grounded choice on the most efficient activities aimed at its minimization was rather rare in Russia; it is a key problem related to practical implementation of health risk analysis methodology in the country.

We highlighted that health risk analysis methodology was successfully applied when "Pure air" federal project was implemented within "Ecology" national project.

We recommended basic stages in assessing efficiency of activities aimed at health risk management, reducing population morbidity and mortality, creating comfortable and favorable urban environment in 12 cities that participated in "Pure air" federal project.

The article also contains suggestions on a unified algorithm based on economic estimation of alternative health risk management techniques and ways to provide sanitary-epidemiologic welfare. The algorithm includes substantiating a necessity to perform examinations and health risk assessment under "basic" exposure, and determining priority problems; assessing residual health risks after each considered activity, assessing efficiency of technological, economic, and health-influencing activities; comparative health risk assessment; health risks ranking taking into account additional effects, as well as technological and economic efficiency; substantiating choice on the most optimal activities and presenting conclusions to decision-makers in the field; giving grounds for a decision being taken.

Key words: risk analysis, risk assessment, risk management, economic estimation, economic efficiency, population health, sanitary-epidemiologic welfare of the population, "Pure air" federal project, ambient air contamination.
\end{abstract}

The most recent data obtained via epidemiologic research in Europe and all over the world indicate that ambient air contamination holds the second place as a risk factor causing non-infectious diseases (NID) after tobacco smoking [1]. Approximately $90 \%$ people in the world have to inhale air with elevated contamination levels and it annually causes about 7 million untimely deaths or 1 death case out of 9 [2]. In 2016 ambient air contamination caused 5.6 million death cases due to NID [3]. World Health Assembly instructed the WHO to take on a leading role in fighting against most significant reasons for

(c) Rakitskii V.N., Avaliani S.L., Novikov S.M., Shashina T.A., Dodina N.S., Kislitsin V.A., 2019

Valerii N. Rakitskii - Doctor of Medical Sciences, Professor, RAS Academician, Acting Director (e-mail: pesticidi@fferisman.ru; tel.: +7 (495) 586-11-44; ORCID: http://orcid.org/0000-0002-9959-6507).

Simon L. Avaliani - Doctor of Medical Sciences, Professor, Head of the Health Risk Analysis Department (e-mail: savaliani@mail.ru; tel.: +7 (495) 586-11-44; ORCID: http://orcid.org/0000-0002-3113-7101).

Sergei M. Novikov - Doctor of Medical Sciences, Professor, Leading researcher at the Health Risk Analysis Department (e-mail: novikserg46@mail.ru; tel.: +7 (495) 586-11-44; ORCID: http://orcid.org/0000-0002-8657-5424).

Tatiana A. Shashina - Candidate of Medical Sciences, Leading researcher at the Health Risk Analysis Department (e-mail: sta815@mail.ru; tel.: +7 (495) 586-11-44; ORCID: http://orcid.org/0000-0002-4190-0326).

Natalia S. Dodina - Candidate of Medical Sciences, Leading researcher at the Health Risk Analysis Department (e-mail: skvnata@mail.ru; tel.: +7 (495) 586-11-44; ORCID: http://orcid.org/0000-0001-6693-922X).

Victor A. Kislitsin - Candidate of Technical Sciences, leading expert at the Children Hygiene Department (e-mail: vak125@rambler.ru; tel.: +7 (495) 586-11-44; ORCID: http://orcid.org/orcid.org./0000-0002-6575-2882). 
untimely death in the world. Up to $98 \%$ of people living in large cities located in lowincome countries can be exposed to ambient air contamination. For example, according to the WHO estimates, cities in Eastern Mediterranean area or in the South-East Asia with not only low incomes but also with average ones have ambient air contamination that is 5-10 times higher than standards recommended by the WHO.

The WHO publications issued over the last ten years give some data confirming that approximately 4.3 million people annually die due to poor air quality indoors; approximately 3 million people die due to outdoor air contamination. Up to $30 \%$ death cases caused by most prevailing noninfectious diseases (strokes, lung cancer, and chronic obstructive pulmonary diseases) and $25 \%$ death cases caused by cardiac infarction are associated with ambient air contamination; this environmental factor produces the most adverse effects on health of women, children, elderly people and lowincome people [4-6].

Apart from ambient air contamination, drastic changes in meteorological parameters also exert their influence on NID prevalence.

Unfavorable weather conditions (heat, temperature inversions etc.) combined with substantial ambient air contamination produce the most hazardous effects as such a combination leads to an increase in additional death cases due to cardiovascular diseases and respiratory diseases [7-10].

Issues related to ambient air contamination and their effects on population health in the Russian Federation are obviously most urgent and require solutions at the state, regional, and municipal levels [11-14].

In order to improve the ecological situation in the country and reduce ambient air contamination in Russian cities, "Ecology" national project was developed and approved by the RF President Order in
2018. "Pure air" federal project is its integral part ${ }^{1}$. By 2024 all the activities that are to be implemented within "Pure air" federal project should result in a $20 \%$-decrease in aggregated volumes of adverse emissions into the atmosphere against their levels in 2017 in Bratsk, Krasnoyarsk, Lipetsk, Mednogorsk, Nizhniy Tagil, Novokuznetsk, Norilsk, Omsk, Chelyabinsk, Cherepovets, and Chita. When implemented, "Pure air" federal project should enable reducing a number of cities with high and extremely high ambient air contamination, creating an efficient system for monitoring and control over ambient air quality, as well as following people's satisfaction with ambient air quality which is also very important.

Another expected result of the project implementation is a fall in mortality and morbidity caused by ambient air contamination in cities that participate in "Pure air" federal project.

Some activities within "Pure air" federal project focus on consolidated calculations of emissions from stationary and mobile sources; apart from that, a complex action plan is to be drawn up for each city, the most significant emission sources such as enterprises or any other are to be identified, exposed areas are to be determined, and effects produced by air-protection activities are to be assessed.

However, multiple research works prove that it is not sufficient to only assess aggregated emissions if we want to develop an efficient policy aimed at making the environment cleaner and healthier [15, 16]. Only comprehensive and in-depth analysis of all the available data on sources of ambient air contamination, impacts exerted by priority contaminants, and, accordingly, population health risks allows assessing whether planned and implemented activities are truly efficient, including their assessment from economic point of view [17-20].

\footnotetext{
${ }^{1}$ The Profile of "Ecology" national project / approved by the Presidium of the RF President Council on strategic development and national projects, the meeting report No. 16 dated December 24, 2018. Available at: http://www.consultant.ru/document/cons_doc_LAW_316096/(date of visit November 12, 2019)
} 
Nowadays, health risk analysis methodology is an optimal approach to assessing whether nature-protecting and recovery activities are efficient and should they be somehow adjusted or supplemented [21].

Over the last 25 years health risk assessment methodology has been successfully applied in many regions in the RF in order to make well-grounded managerial decisions as regards providing ambient air quality and sanitary-epidemiologic welfare of the population. Health risk assessment allowed identifying leading risk factors in each particular research; determining population groups that were the most susceptible to adverse effects; ranking territories as per health risks both in the current situation and in probable future ones related to changes in economic activities, primarily industries and transport.

Accumulated experience indicates that most studies on health risk analysis that are performed in Russia mostly focus on its first stage or health risk assessment that allows determining whether calculated risk levels are acceptable or not [22-26]. And risk analysis in this case rarely covers any issues related to risk management together with substantiating the most efficient measures required to minimize it. This methodology can be applied successfully only provided that implemented activities are analyzed and this analysis is aimed at determining maximum possible reduction in risk level that can be achieved due to them with the minimum possible expenses required for their implementation.

At present there are some scientific and methodological documents $2,3,4,5$ that fix approaches to how to make economic estimations and substantiate decisions regarding health risk management under exposure to various environmental factors including ambient air contamination.

These documents provide a detailed insight into assessing cost efficiency as regards variable managerial decisions, in particular, when substantiating sizes of a sanitary-protection zone taking into account any planned reconstruction of industrial facilities; when planning how to rehabilitate health of people who live on contaminated territories, etc.

However, in order to optimize practical implementation of risk analysis within "Pure air" federal project, it is advisable to apply a unified algorithm based on economic estimation of different options for managing health risks and providing sanitary-epidemiologic welfare.

When investment projects are properly ranked, it provides valuable information for decision-makers who are responsible for choosing the best available ones; such choices are to be based on a combination of maximum possible economic efficiency of a project with maximum possible effects related to protecting people from exposure to chemicals that contaminate ambient air.

A step-by-step algorithm for assessing health risks and damage to health applied to substantiate ways to manage risks caused by exposure to ambient air contamination (assessing how efficient implemented activities are) contains the following stages: substantiating a necessity to perform examinations, health risk assessment under "reference"

${ }^{2} \mathrm{G}$ 2.1.10.1920-04. Guide on health risk assessment under exposure to chemicals that pollute the environment. Moscow, The Federal Center for State Sanitary and Epidemiologic Surveillance of the RF Public healthcare Ministry, 2004, 143 p.

${ }^{3} \mathrm{MG}$ 5.1.0030-11. Methodical guidelines for economic estimates and substantiating decisions regarding health risk management under exposure to environmental factors. KODEKS: an electronic fund of legal and reference documentation. Available at: http://docs.cntd.ru/document/1200088393 (date of visit December 01, 2019).

${ }^{4}$ MG 2.1.10.0033-11. Assessment of risks caused by effects produced on health by lifestyle-related factors. KODEKS: an electronic fund of legal and reference documentation. Available at: http://docs.cntd.ru/document/1200111974 (date of visit December 01, 2019).

${ }^{5}$ MG 2.1.10.0057-12. Assessment of risk and damage caused by climatic changes that influence morbidity and mortality among population groups who run elevated health risks. KODEKS: an electronic fund of legal and reference documentation. Available at: http://docs.cntd.ru/document/1200096653 (date of visit December 01, 2019). 


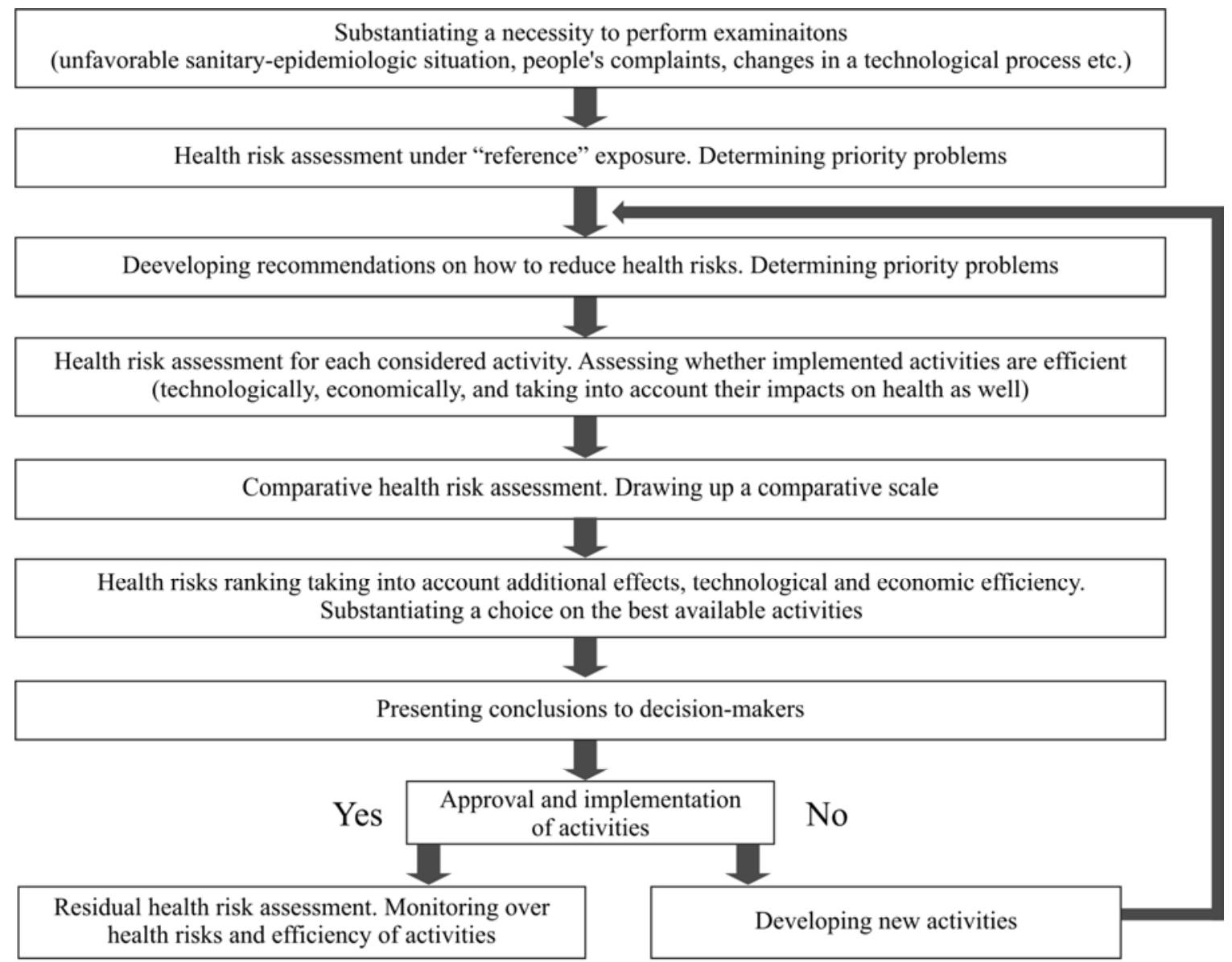

Figure. An algorithm for assessing health risks and damage to health for substantiating a choice on risk management techniques under exposure to ambient air contamination (assessing how efficient implemented activities are)

exposure, and determining priority problems; assessment of residual health risks after each considered activity, assessment whether implemented activities are efficient (technologically, economically, and taking into account their impacts on health as well); comparative health risk assessment; ranking health risks taking into account additional effects, technological and economic efficiency, substantiating a choice on the best available activities; providing decisionmakers with all the conclusions that allow giving grounds for a taken decision (Figure).

Should such an algorithm be implemented, it will allow developing a possible scenario how to reduce risks caused by stationary and mobile sources of ambient air contamination; this scenario envisages any reduction in health risks to be achieved with least possible costs.

As we have already noted, ambient air contamination and its probable effects on population health are a truly pressing issue. We believe that "Pure air" federal project as an integral part of "Ecology" national project can be successfully implemented only if there are well-coordinated interdepartmental efforts to make targeted managerial decisions aimed at decreasing ambient air contamination, reducing health risks, and providing sanitaryepidemiologic welfare of the population.

Funding. The research was not granted any sponsor support.

Conflict of interests. The authors declare there is no any conflict of interests. 


\section{References}

1. Neinfektsionnye zabolevaniya i zagryaznenie atmosfernogo vozdukha [Non-infectious diseases and ambient air contamination]. World Health Organization, 2019, 12 p. Available at: http://www.euro.who.int/_data/assets/pdf_file/0006/397788/Air-Pollution-and-

NCDs_RUS.pdf?ua $=1$ (01.12.2019) (in Russian).

2. Air pollution. World Health Organization, 2018. Available at: https://www.who.int/newsroom/fact-sheets/detail/ambient-(outdoor)-air-quality-and-health (01.12.2019).

3. Global Health Observatory - Data repository. World Health Organization, 2018. Available at: http://www.who.int/gho/database/en/ (01.12.2019).

4. Health risks of air pollution in Europe - HRAPIE project Recommendations for concentration-response functions for cost-benefit analysis of particulate matter, ozone and nitrogen dioxide. World Health Organization, 2013, 60 p.

5. Landrigan P.J., Fuller R., Acosta N.J.R., Adeyi O., Arnold R., Basu N.N., Baldé A.B., Bertollini R. [et al.]. The Lancet Commission on pollution and health. Lancet, 2018, vol. 3, no. 391, pp. 462-512. DOI: 10.1016/S0140-6736(17)32345-0 pmid:29056410

6. Gayer A., Adamkiewicz Ł., Mucha D., Badyda A. Air quality health indices - Review. MATEC Web of Conferences, 2018, vol. 247, pp. 00002. DOI: 10.1051/matecconf/201824700002

7. Revich B.A., Avaliani S.L., Simons G.J. Air pollution and public health in a megalopolis: a case study of Moscow. Ekonomika regiona, 2016, vol. 12, no. 4, pp. 1069-1078.

8. Draft WHO global strategy on health, environment and climate change. World Health Organization, 2018. Available at: https://www.who.int/phe/publications/global-strategy/en/ (10.12.2019).

9. Shartova N., Konstantinov P., Shaposhnikov D., Revich B. Cardiovascular mortality during heat waves in temperate climate: an association with bioclimatic indices. International Journal of Environmental Health Research, 2018, vol. 28, no. 5, pp. 522-534. DOI: 10.1080/09603123.2018.1495322

10. Revich B.A., Shaposhnikov D.A., Anisimov O.A., Belolutskaya M.A. Impact of temperature waves on the health of residents in cities of the northwestern region of Russia. Problemy prognozirovaniya, 2019, vol. 3, no. 174, pp. 127-134 (in Russian).

11. Popova A.Yu. Strategic priorities of the Russian Federation in the field of ecology from the position of preservation of health of the nation. Zdorov'e naseleniya i sreda obitaniya, 2014, vol. 251, no. 2, pp. 4-7 (in Russian).

12. WHO Expert Meeting: Methods and tools for assessing the health risks of air pollution at local, national and international level. World Health Organization, 2014, 112 p. (in Russian).

13. Zaitseva N.V. Effektivnost' i rezervy dostizheniya strategicheskikh prioritetov v snizhenii neinfektsionnykh zabolevanii, svyazannykh s faktorami okruzhayushchei sredy [Efficiency and reserves for achieving strategic priority goals in reducing non-infectious diseases related to environmental factors]. Aktual'nye voprosy analiza riska pri obespechenii sanitarno-epidemiologicheskogo blagopoluchiya naseleniya i zashchity prav potrebitelei: sbornik po materialam IX Vserossiiskoi nauchno-prakticheskoi konferentsii s mezhdunarodnym uchastiem. In: A.Yu. Popova, N.V. Zaitseva eds. Perm, 2019, pp. 7-12 (in Russian).

14. Sostoyanie zagryazneniya atmosfery v gorodakh na territorii Rossii za 2018 god. Ezhegodnik [Ambient air contamination in cities in Russia in 2018. Annual edition]. Sankt-Peterburg, Federal'naya sluzhba po gidrometeorologii i monitoringu okruzhayushchei sredy (Rosgidromet), Glavnaya geofizicheskaya observatoriya im. A.I. Voeikova Publ., 2019, 251 p. (in Russian).

15. Rakhmanin Y.A., Novikov S.M., Avaliani S.L., Sinitsyna O.O., Shashina T.A. Actual problems of environmental factors risk assessment on human health and ways to improve it. Health Risk Analysis, 2015, no. 2, pp. 4-14 (in Russian). DOI: 10.21668/health.risk/2015.2.01.eng

16. Novikov S.M., Fokin M.V., Unguryanu T.N. Actual problem of methodology and development of evidence-based health risk assessment associated with chemical exposure. Gigiena $i$ sanitariya, 2016, vol. 95, no. 8, pp. 711-716 (in Russian).

17. Onishchenko G.G., Novikov S.M., Rakhmanin Yu.A., Avaliani S.L., Bushtueva K.A. Osnovy otsenki riska dlya zdorov'ya naseleniya pri vozdeistvii khimicheskikh veshchestv, zagryaznyayushchikh okruzhayushchuyu sredu [Basics of health risk assessment under exposure to chemicals that pollute the environment]. In: Yu.A. Rakhmanin, G.G. Onishchenko eds. Moscow, Nauchno- 
issledovatel'skii institut ekologii cheloveka i gigieny okruzhayushchei sredy imeni A.N. Sysina Publ., 2002, 408 p. (in Russian).

18. Onischenko G.G. Health risk assessment and management as an effective tool to solve issues to ensure the health and epidemiological well-being of the Russian Federation population. Health Risk Analysis, 2013, no. 1, pp. 4-14 (in Russian). DOI: 10.21668/health.risk/2013.1.01.eng

19. Onishchenko G.G., Zaitseva N.V., May I.V., Shur P.Z., Popova A.Yu., Alekseev V.B., Dolgikh O.V., Zemlyanova M.A. [et al.]. Analiz riska zdorov'yu v strategii gosudarstvennogo sotsial'noekonomicheskogo razvitiya [Health risk analysis in the strategy for the state social and economic development]. In: G.G. Onishchenko, N.V. Zaitseva eds. Moscow, Perm, Izdatel'stvo permskogo natsional'nogo issledovatel'skogo politekhnicheskogo universiteta Publ., 2014, 738 p. (in Russian).

20. WHO Regional Office for Europe, OECD (2015). Economic cost of the health impact of air pollution in Europe: Clean air, health and wealth. World Health Organization. Copenhagen, WHO Regional Office for Europe Publ., 2015, 54 p.

21. Popova A.Yu., Gurvich V.B., Kuz'min S.V., Mishina A.L., Yarushin S.V. Modern issues of the health risk assessment and management. Gigiena i sanitariya, 2017, vol. 96, no. 12, pp. 1125-1129 (in Russian).

22. Avaliani S.L., Bushtueva K.A., Gudkevich A.Z. [et al.]. Obosnovanie prioritetnosti prirodookhrannykh meropriyatii v Samarskoi oblasti na osnove effektivnosti zatrat po snizheniyu riska dlya zdorov'ya naseleniya [Substantiating priorities in environmental measures in Samara region based on cost effectiveness of activities aimed at reducing population health risks]. Moscow, Konsul'tatsionnyi tsentr po otsenke riska Publ., 1999, 209 p. (in Russian).

23. Avaliani S.L., Novikov S.M., Bushtueva K.A. [et al.]. Upravlenie riskom dlya zdorov'ya v regione i finansirovanie prirodookhrannykh proektov (na primere Velikogo Novgoroda) [Health risk management in a region and funding for environmental projects (on the example of Velikiy Novgorod)]. Moscow, Tsentr ekologo-gigienicheskikh issledovanii Publ., 1999, 65 p. (in Russian).

24. Gurvich V.B., Kuzmin S.V., Dikonskaya O.V., Malykh O.L., Yarushin S.V. Health risk management to provide health and epidemiological well-being to the population in municipalities (the experience of the Sverdlovsk region). Health Risk Analysis, 2013, no. 3, pp. 64-74 (in Russian). DOI: $10.21668 /$ health.risk/2013.3.08.eng

25. Onishchenko G.G., Popova A.Yu., Zaitseva N.V., May I.V., Shur P.Z. Health risk analysis in the tasks of improving sanitary and epidemiological surveillance in the Russian Federation. Health Risk Analysis, 2014, no. 2, pp. 4-13 (in Russian). DOI: 10.21668/health.risk/2014.2.01.eng

26. Avaliani S.L., Novikov S.M., Shashina T.A., Dodina N.S., Kislitsin V.A., Mishina A.L. The urgent problems of the improvement of the environment management system based on the analysis of health risk assessment. Gigiena i sanitariya, 2014, vol. 93, no. 6, pp. 5-9 (in Russian).

Rakitskii V.N., Avaliani S.L., Novikov S.M., Shashina T.A., Dodina N.S., Kislitsin V.A. Health risk analysis related to exposure to ambuent air contamination as a component in the strategy aimed at reducing global non-infectious epidemics. Health Risk Analysis, 2019, no. 4, pp. 30-36. DOI: 10.21668/health.risk/2019.4.03.eng

Received: 17.11.2019

Accepted: 19.12 .2019

Published: 30.12.2019 